\title{
EKSTRAKSI PADAT-CAIR ZnO DENGAN ASAM DARI DEBU FILTER PROSES PEMBUATAN BAJA
}

\author{
Ricson P Hutagaol*, Nasrudin, Agus Taufik \\ Laboratorium Kimia Universitas Nusa Bangsa \\ J1 KH Soleh Iskandar KM 4. Cimanggu Tanah Sareal Bogor 16166 \\ *e-mail: rics_htgl@yahoo.com
}

\begin{abstract}
ZnO Solid - Liquid Extraction with Filter Dust Acid from The Steel Making Proccess

Zinc Oxide is a white metal oxide which is widely used in various industries. Zinc oxide can be produced with the direct, indirect process (method of France) and hydrometallurgical. Source manufacture $\mathrm{ZnO}$ derived from material containing zinc metal. The content of $\mathrm{ZnO}$ in the dust filter in the steel making process as a potential raw material for the manufacture of $\mathrm{ZnO}$. The purpose of this study was to determine the type of acid and concentration were better for extraction $\mathrm{ZnO}$ viewed from purity and the yield. This research was conducted by method of solid-liquid extraction, followed by the presipitation process. Testing of purity of $\mathrm{ZnO}$ with better extraction result were $\mathrm{H}_{2} \mathrm{SO}_{4} 0,75 \mathrm{M}$ was $89.67 \%$ with a yield of $97.73 \%$, while the $\mathrm{H}_{2} \mathrm{SO}_{4} 0,50 \mathrm{M}$ was $80.45 \%$ (yield $63.96 \%$ ), $\mathrm{H}_{2} \mathrm{SO}_{4} 0,25 \mathrm{M}$ was $76,48 \%$ (46.95\% yield), $\mathrm{HCl} 0,75 \mathrm{M}$ was $79.23 \%$ (81.70\% yield), $\mathrm{HCl} 0,50 \mathrm{M}$ was $76.98 \%$ (yield $49 \%$ ), and $\mathrm{HCl} 0,25 \mathrm{M}$ was $74.57 \%$ (30.23\% yield). $\mathrm{ZnO}$ composition data from extraction results were analyzed using $X$-ray fluorescence $(X R F)$.
\end{abstract}

Key words: Solid-liquid extraction, ZnO, Dust, Steel, XRF

\begin{abstract}
ABSTRAK
Seng Oksida merupakan oksida logam berwarna putih yang banyak digunakan di berbagai industri. Seng oksida dapat diproduksi dengan proses langsung, proses tidak langsung (metode Prancis) dan hidrometalurgi. Sumber pembuatan $\mathrm{ZnO}$ berasal dari material yang mengandung logam seng. Kandungan $\mathrm{ZnO}$ dalam debu filter pada proses pembuatan baja berpotensi sebagai bahan baku untuk pembuatan $\mathrm{ZnO}$. Tujuan dari penelitian ini adalah menentukan jenis asam dan konsentrasi yang lebih baik untuk ekstraksi $\mathrm{ZnO}$ dilihat dari kemurnian dan rendemennya. Penelitian ini dilakukan dengan metode ekstraksi padat-cair yang dilanjutkan dengan proses pengendapan. Pengujian kemurnian $\mathrm{ZnO}$ hasil ekstraksi yang lebih baik yaitu $\mathrm{H}_{2} \mathrm{SO}_{4} 0,75 \mathrm{M}$ adalah $89,67 \%$ dengan rendemen $97,73 \%$, sedangkan $\mathrm{H}_{2} \mathrm{SO}_{4} \quad 0,50 \mathrm{M}$ adalah $80,45 \%$ (rendemen 63,96), $\mathrm{H}_{2} \mathrm{SO}_{4} 0,25 \mathrm{M}$ adalah 76,48\% (rendemen 46,95\%), $\mathrm{HCl} 0,75 \mathrm{M}$ adalah 79,23\% (rendemen 81,70\%), $\mathrm{HCl} 0,50 \mathrm{M}$ adalah 76,98\% (rendemen 49\%), dan $\mathrm{HCl} 0,25 \mathrm{M}$ adalah 74,57\% (rendemen 30,23\%). Data komposisi hasil ekstraksi $\mathrm{ZnO}$ yang dianalisis menggunakan $X$-ray fluorescence (XRF).
\end{abstract}

Kata Kunci : Ekstraksi padat-cair, ZnO, Debu Baja, XRF

\section{PENDAHULUAN}

Sebuah furnace atau tungku selalu dilengkapi beberapa peralatan pendukung untuk membantu kelancaran proses pembuatan baja. Salah satunya adalah penghisap debu dan asap. Penghisap debu dan asap ini berguna untuk menghisap debu halus atau zat terbang yang ada di dalam tanur. Secara umum, kandungan debu yang terhisap dari dalam tungku adalah 20-30\% seng dan $15-30 \%$ Besi, yang berpotensi menjadi sumber seng dan logam besi (Wannakamb, 2013).
Zink oksida adalah senyawa anorganik berwarna putih yang banyak digunakan di industry plastik, keramik, rubber (karet), cat, kosmetik bahkan $\mathrm{ZnO}$ dalam ukuran nano banyak digunakan sebagai semikonduktor. Zink oksida secara luas diproduksi menggunakan proses kering (proses Perancis), dimana oksidasi uap zink di udara dari zink yang dibakar pada suhu $1100^{\circ} \mathrm{C}$ (Hyman, 1989).

Selain proses Perancis, $\mathrm{ZnO}$ juga dapat diproduksi dengan proses hidrometalurgi, yaitu dengan proses ekstraksi 
padat-cair, pemekatan larutan dan proses recovery atau bisa juga dengan proses elektrolisis. Proses Hidrometalurgi sangat cocok digunakan untuk ekstraksi $\mathrm{ZnO}$ dengan kadar rendah.

Zink oksida larut dalam asam maupun basa. Pada asam sulfat encer dan asam klorida encer, zink oksida mudah larut dan menghasilkan gas hidrogen, sedangkan pada hidroksida alkali membentuk ion kompleks dan melepaskan gas hidrogen. Kelarutan $\mathrm{ZnO}$ dalam asam dan basa me-mungkinkan $\mathrm{ZnO}$ untuk diekstrak dengan jenis asam dan basa tersebut. Setelah proses pelarutan, beberapa logam yang larut dipisahkan dengan penambahan beberapa bahan kimia dan proses penyaringan. Zink yang murni diendapkan dengan senyawa hidroksida dan dipanaskan untuk mendapatkan senyawa $\mathrm{ZnO}$ murni.

\section{BAHAN DAN METODE}

\section{Bahan}

Bahan yang digunakan pada penelitian ini terdiri dari sampel debu filter pada proses pembuatan baja yang berasal dari PT. Growth Sumatra Medan dan bahan kimia yang digunakan adalah methyl cellulose, $\mathrm{H}_{2} \mathrm{SO}_{4} 0,25 \mathrm{M} ; 0,50 \mathrm{M}$; dan $0,75 \mathrm{M}$, $\mathrm{HCl} 0,25 \mathrm{M} ; 0,50 \mathrm{M}$; dan $0,75 \mathrm{M}, \mathrm{H}_{2} \mathrm{O}_{2} 30 \%, \mathrm{CaCO}_{3}, \mathrm{Na}_{2} \mathrm{CO}_{3}$ jenuh, $\mathrm{HCl}$ (1:1), larutan buffer $\mathrm{pH} 5$, xylenol Orange $0,1 \%$, EDTA $0,05 \mathrm{M}$, $\mathrm{K}_{2} \mathrm{Cr}_{2} \mathrm{O}_{7} 0,1 \mathrm{~N}, \mathrm{SnCl}_{2} 10 \%$, dan $\mathrm{HgCl}_{2}$ $10 \%$.

\footnotetext{
Alat

Alat yang digunakan adalah hotplate stirrer, magnetic stirrer, neraca analitik tipe Hengping, Neraca analitik Shimadzu tipe AUY120, ARL Optim'X (XRF), indikator universal, buret, heater, termometer, kertas saring, O-ring, muffle furnace, oven, botol reaksi $1 \mathrm{~L}$, erlenmeyer $250 \mathrm{~mL}$, Labu ukur dan cawan porselen $100 \mathrm{~mL}$.
}

\section{Metode}

\section{Analisis Debu Filter}

Sebanyak $10 \mathrm{~g}$ sampel debu halus (200 mesh) ditambahkan $1 \mathrm{~g}$ methyl cellulose. Campuran kemudian dihomogenkan dan dihaluskan kembali menggunakan seal type mill (mesin grinding) selama 180 detik. Sampel yang sudah halus kemudian ditimbang sebanyak 8 g kemudian ditekan dengan full automatic tablet machine (mesin tekan) dengan kekuatan 12.5 Mpa. Sampel yang sudah berbentuk tablet kemudian dianalisis menggunakan XRF dengan program OptiQuant ${ }^{\circledR}$

\section{Proses Ekstraksi padat cair dengan Asam Sulfat}

Sebanyak $50 \mathrm{~g}$ sampel dilarutkan dengan $500 \mathrm{~mL}$ asam sulfat $0,25 \mathrm{M}, 0,5$ $\mathrm{M}$ dan $0,75 \mathrm{M}$ kedalam botol $1000 \mathrm{~mL}$. Campuran diaduk dengan magnetic stirrer diatas hotplate stirrer pada suhu $90^{\circ} \mathrm{C}$ dengan kecepatan putaran $400 \mathrm{rpm}$ selama 24 jam. Kemudian campuran disaring menggunakan kertas saring. Larutan kemudian ditambahkan $10 \mathrm{~mL}$ $\mathrm{H}_{2} \mathrm{O}_{2} 30 \%$ dan kapur $\left(\mathrm{CaCO}_{3}\right)$. Setelah itu campuran difiltrasi dan larutan kemudian ditambahkan $\mathrm{Na}_{2} \mathrm{CO}_{3}$ jenuh. Endapan kemudian disaring dan endapan yang dihasilkan dikalsinasi pada suhu $450^{\circ} \mathrm{C}$.

\section{Proses Ekstraksi Padat Cair dengan Asam Klorida}

Sebanyak $50 \mathrm{~g}$ sampel dilarutkan dengan $500 \mathrm{~mL}$ asam klorida $0,25 \mathrm{M}, 0,5$ $\mathrm{M}$ dan $0,75 \mathrm{M}$ kedalam botol $1000 \mathrm{~mL}$. Campuran diaduk dengan hotplate stirrer pada suhu $90^{\circ} \mathrm{C}$ dengan kecepatan putaran $400 \mathrm{rpm}$ selama 24 jam. Kemudian campuran disaring menggunakan kertas saring. Larutan kemudian ditambahkan $10 \mathrm{~mL} \mathrm{H}_{2} \mathrm{O}_{2} 30 \%$ dan kapur. Setelah itu campuran difiltrasi dan larutan kemudian ditambahkan $\mathrm{Na}_{2} \mathrm{CO}_{3}$ jenuh. Endapan kemudian disaring dan dikalsinasi pada suhu $450^{\circ} \mathrm{C}$.

\section{Analisis Kadar $\mathrm{ZnO}$ hasil ektraksi}

Sebanyak 1,5 g sampel dimasukan kedalam gelas piala $500 \mathrm{~mL}$ dan 
ditambahkan $50 \mathrm{~mL}$ aquadest dan $20 \mathrm{~mL}$ $\mathrm{HCl}$ (1:1). Panaskan sampai larut sempurna, kalau perlu, tambahkan 1-3 tetes $\mathrm{HNO}_{3}$ pekat agar larut sempurna. Setelah dingin, larutan dimasukan ke dalam labu ukur $250 \mathrm{~mL}$ dan diencerkan dengan aquades sampai tanda tera dan dihomogenkan. Larutan dipipet sebanyak $25 \mathrm{~mL}$ dan dimasukan kedalam erlenmeyer $250 \mathrm{~mL}$ dan tambahkan 10 $\mathrm{mL}$ larutan buffer $\mathrm{pH} 5$. $\mathrm{pH}$ larutan diatur antara 5-5,5 dengan menambahkan larutan ammonia (1:1). Titar dengan larutan EDTA $0.05 \quad \mathrm{M}$ dengan menggunakan $0,5 \mathrm{~mL}$ larutan xylenol orange $0,1 \%$ hingga warna larutan berubah dari merah jingga kemudian merah dan akhirnya menjadi kuning.

\section{Perhitungan}

a. Pengukuran kadar $\mathrm{ZnO}$

Kadar $\mathrm{ZnO}(\%)=\frac{0,004068 \times \mathrm{V}_{\text {EDTA }} \times(250 / 25)}{\text { Bobot sampel }} \times 100 \%$

b. Perhitungan Rendemen

Rendemen $=\frac{\text { Bobot } \mathrm{ZnO} \text { hasil leaching }}{\% \mathrm{ZnO} \text { dalam debu } \mathrm{x} \text { bobot sampel }} \times 100 \%$

\section{HASIL DAN PEMBAHASAN}

Sampel yang digunakan dalam penelitian ini diperoleh dari debu sisa pembuatan baja menggunakan tanur listrik (Dust Electric Arch Furnace) dari PT. Growth Sumatra. Sampel berwarna coklat dengan ukuran 100 mesh.

Debu sisa pembakaran baja yang dikenal dengan istilah DEAF berasal dari material halus yang dimasukan kedalam tanur kemudian dihisap dibagian gasparator dan sebagian lagi berasal dari logam yang menguap pada suhu dibawah suhu peleburan baja. Hasil analisis debu sisa pembuatan baja dapat dilihat pada Tabel 1.

Berdasarkan dari data hasil analisis $\mathrm{XRF}$ diatas, tingginya kandungan $\mathrm{ZnO}$ dalam debu filter pada proses pembuatan baja ini dapat dimanfaatkan menjadi sumber pembuatan $\mathrm{ZnO}$ dengan cara ekstraksi. Proses ekstraksi dilakukan dengan larutan asam, maka $\mathrm{ZnO}$ akan bereaksi dengan asam sulfat membentuk $\mathrm{ZnSO}_{4}$ dan jika dengan $\mathrm{HCl}$ akan membentuk larutan $\mathrm{ZnCl}_{2}$.

\section{A. Proses Ekstraksi}

Ekstraksi $\mathrm{ZnO}$ dari abu sisa pembakaran baja dalam penelitian ini dilakukan dengan menggunakan 2 jenis asam, masing-masing memiliki variasi konsentrasi $0,25 \mathrm{M}, 0,50 \mathrm{M}$, dan $0,75 \mathrm{M}$. Abu sisa pembakaran baja sebanyak $50 \mathrm{~g}$ diekstrak dengan $500 \mathrm{~mL}$ pelarut yang berbeda jenis asamnya. Pelarut yang digunakan yaitu asam klorida $(\mathrm{HCl})$ dan asam sulfat $\left(\mathrm{H}_{2} \mathrm{SO}_{4}\right)$.

Menurut Yoshida (2003) reaksi antara Zink oksida dengan asam sulfat dan asam klorida adalah:

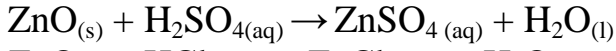
$\mathrm{ZnO}_{(\mathrm{s})}+\mathrm{HCl}_{(\mathrm{aq})} \rightarrow \mathrm{ZnCl}_{2(\mathrm{aq})}+\mathrm{H}_{2} \mathrm{O}_{(\mathrm{l})}$

Mekanisme rekasi yang terjadi adalah difusi reagent kimia ke permukaan $\mathrm{ZnO}$ melalui lapisan batas cair dan reaksi ekstraksi terjadi pada permukaan spesiment. Setelah itu, hasil reaksi akan berpindah dari permukaan ke larutan leaching melalui batas permukaan $\mathrm{ZnO}$. Kinetika reaksi leaching pada dasarnya adalah campuran dari reaksi kimia dan perpindahan senyawa.

Tabel 1. Hasil Analisis Debu Sisa Pemba-karan Baja dari PT. Growth Sumatera Indonesia

\begin{tabular}{cc}
\hline Senyawa & Sisa Pembakaran \\
\hline $\mathbf{Z n O}$ & $26,08 \%$ \\
$\mathbf{S i O}_{2}$ & $12,26 \%$ \\
$\mathbf{F e}_{2} \mathbf{O}_{3}$ & $29,41 \%$ \\
$\mathbf{M g O}$ & $10,10 \%$ \\
$\mathrm{Al}_{2} \mathbf{O}_{3}$ & $2,24 \%$ \\
$\mathbf{C a O}$ & $8,34 \%$ \\
$\mathbf{S}$ & $1,46 \%$ \\
$\mathbf{N a}_{2} \mathbf{O}$ & $1,75 \%$ \\
\hline
\end{tabular}


Asam sulfat $\left(\mathrm{H}_{2} \mathrm{SO}_{4}\right)$ memiliki tingkat kereaktifan yang paling tinggi dibanding asam klorida $(\mathrm{HCl})$ dalam penelitian ini dikarenakan $\mathrm{ZnO}$ dalam abu sisa pem-bakaran baja ini akan mudah larut dalam $\mathrm{H}_{2} \mathrm{SO}_{4}$ dalam konsentrasi rendah (encer). Reaksi yang terjadi antara $\mathrm{ZnO}$ dengan asam sulfat akan menghasilkan garam $\mathrm{ZnSO}_{4}$ yang cenderung bersifat asam. $\mathrm{ZnO}$ yang bersifat amfoter dalam reaksi ini menunjukan sifat basanya karena bereaksi dengan asam kuat, yaitu $\mathrm{H}_{2} \mathrm{SO}_{4}$.

Menurut Havlik (2004), dalam abu sisa pembakaran baja juga mengandung $\mathrm{ZnFe}_{2} \mathrm{O}_{4}$ yang bereaksi dengan $\mathrm{H}_{2} \mathrm{SO}_{4}$ dan $\mathrm{HCl}$ dengan reaksi sebagai berikut:

$$
\begin{aligned}
\mathrm{ZnFe}_{2} \mathrm{O}_{4}+4 \mathrm{H}_{2} \mathrm{SO}_{4} \rightarrow & \mathrm{ZnSO}_{4}+\mathrm{Fe}_{2}\left(\mathrm{SO}_{4}\right)_{3} \\
& +4 \mathrm{H}_{2} \mathrm{O} \\
\mathrm{ZnFe}_{2} \mathrm{O}_{4}+\mathrm{H}_{2} \mathrm{SO}_{4} \rightarrow & \mathrm{ZnSO}_{4}+\mathrm{Fe}_{2} \mathrm{O}_{3} \\
& +\mathrm{H}_{2} \mathrm{O} \\
\mathrm{ZnFe}_{2} \mathrm{O}_{4}+4 \mathrm{HCl} \rightarrow & \mathrm{ZnCl}_{2}+\mathrm{Fe}_{2} \mathrm{Cl}_{3} \\
& +4 \mathrm{H}_{2} \mathrm{O} \\
\mathrm{ZnFe}_{2} \mathrm{O}_{4}+\mathrm{HCl} \rightarrow & \mathrm{ZnCl}+\mathrm{Fe}_{2} \mathrm{O}_{3}+\mathrm{H}_{2} \mathrm{O}
\end{aligned}
$$

Adanya senyawa $\mathrm{Zn}$ yang berikatan dengan $\mathrm{Fe}$ dalam bentuk $\mathrm{ZnFe}_{2} \mathrm{O}_{4}$ dan $\mathrm{Fe}_{2} \mathrm{O}_{3}$ dalam debu filter menyebabkan terlarutnya ion $\mathrm{Fe}$. Sehingga $\mathrm{Fe}$ harus dipisahkan dengan cara pengendapan terlebih dahulu.

\section{B. Hasil Ekstraksi ZnO}

Sampel hasil ekstraksi mengandung ion $\mathrm{Zn}, \mathrm{Fe}$, dan beberapa ion lain dalam konsentrasi rendah. Adanya ion selain $\mathrm{Zn}$, maka harus ada pemisahan ion-ion selain Zn, salah satunya yaitu dengan pengendapan ion lain, dalam hal ini, ion $\mathrm{Fe}$ diendapkan dengan $\mathrm{CaCO}_{3}$ dan $\mathrm{H}_{2} \mathrm{O}_{2}$. Tujuan penambahan $\mathrm{H}_{2} \mathrm{O}_{2}$ (hidrogen peroxide) adalah untuk mengoksidasi $\mathrm{Fe}^{2+}$ menjadi $\mathrm{Fe}^{3+}$ agar bisa bereaksi dengan $\mathrm{CaCO}_{3}$. Endapan yang terbentuk adalah endapan Fe berwarna merah. Pada penambahan ini, $\mathrm{pH}$ dipertahankan pada 4-5 agar tidak terjadi pengendapan $\mathrm{ZnCO}_{3}$. Reaksi yang terjadi adalah:

$2 \mathrm{Fe}^{2+}+\mathrm{H}_{2} \mathrm{O}_{2}+2 \mathrm{H}^{+} \rightarrow 2 \mathrm{Fe}^{3+}+\mathrm{H}_{2} \mathrm{O}$
$2 \mathrm{Fe}^{3+}+3 \mathrm{CaCO}_{3} \rightarrow \mathrm{Fe}_{2}\left(\mathrm{CO}_{3}\right)_{3}+3 \mathrm{Ca}^{2+}$

$\mathrm{Fe}_{2}\left(\mathrm{CO}_{3}\right)_{3} \rightarrow \mathrm{Fe}_{2} \mathrm{O}_{3(\mathrm{~s})}+3 \mathrm{CO}_{2(\mathrm{~g})}$

Larutan yang mengandung ion $\mathrm{Zn}$ yang bebas dari ion $\mathrm{Fe}$ kemudian diendapkan dengan natrium karbonat jenuh $\left(\mathrm{Na}_{2} \mathrm{CO}_{3}\right)$ membentuk endapan $\mathrm{ZnCO}_{3}$ yang berwarna putih. Untuk memurnikan $\mathrm{ZnO}, \mathrm{ZnCO}_{3}$ dikalsinasi dengan pemanasan pada suhu $450^{\circ} \mathrm{C}$.

Dari bentuk morfologinya, banyaknya bentuk yang tidak sama menandakan banyaknya senyawa yang terkandung di dalam debu filter tersebut. Setelah dilakukan ekstraksi dengan $\mathrm{H}_{2} \mathrm{SO}_{4}$ dan $\mathrm{HCl}$, bentuk morfologinya lebih terlihat seragam diban-dingkan dengan sebelum ekstraksi, artinya senyawa yang terkandung di dalam hasil ekstraksi tidak terlalu banyak pengotornya atau hampir murni.

Apabila dilakukan perbandingan bentuk morfologi antara hasil ekstraksi dengan $\mathrm{H}_{2} \mathrm{SO}_{4}, \mathrm{HCl}$, dan hasil ekstraksi $\mathrm{ZnO}$ yang dilakukan oleh Oustadakis (2010), maka bentuk morfologi yang di tampilkan adalah bentuk $\mathrm{ZnO}$. Hasil ekstraksi dengan $\mathrm{H}_{2} \mathrm{SO}_{4}$ lebih seragam dibandingkan dengan $\mathrm{HCl}$, menandakan $\mathrm{ZnO}$ lebih banyak terikat pada saat ekstraksi dengan $\mathrm{H}_{2} \mathrm{SO}_{4}$ dibandingkan dengan $\mathrm{HCl}$. Banyaknya morfologi $\mathrm{ZnO}$, maka hasil ekstraksi dengan $\mathrm{H}_{2} \mathrm{SO}_{4}$ lebih murni jika dibandingkan dengan $\mathrm{HCl}$.

Endapan hasil ekstraksi dianalisis dengan methode titrimetri (SNI 0085:2009) untuk mengetahui kadar $\mathrm{ZnO}$ dalam sample hasil pegendapan. Pada methode ini, di-gunakan EDTA 0,05 M sebagai titar dan xylenol orange $0,1 \%$ sebagai indikatornya. Sample harus dipastikan berada di $\mathrm{pH}=5-5,5$ sebelum dilakukan titrasi supaya hanya $\mathrm{ZnO}$ yang bereaksi dengan EDTA. Endapan juga dihitung rendemennya dari kadar awalnya (kadar $\mathrm{ZnO}$ dalam debu filter). Hasil ekstraksi dengan menggunakan Asam Sulfat terdapat pada Tabel 2.

Dari Tabel 2, berdasarkan pengujian hasil ekstraksi secara titrimetri, konsentrasi yang paling baik untuk menghasilkan kemurnian $\mathrm{ZnO}$ yang tinggi adalah pada konsentrasi $0,75 \mathrm{M}$ 
yaitu $89,67 \%$ dengan rendemen sebesar $97,73 \%$. Sedangkan pada konsentrasi $0,25 \mathrm{M}$, kemurnian yang di-peroleh hanya $76,48 \%$ dengan rendemen $46,95 \%$. Data hasil analisis secara titrimetri ini didukung oleh hasil analisis dengan menggunakan XRF yang ditampilkan pada Tabel 4, sehingga data hasil analisis ini dapat dipertanggung jawabkan. Dari data tersebut, semakin tinggi konsentrasi $\mathrm{H}_{2} \mathrm{SO}_{4}$ yang digunakan, semakin banyak dan semakin murni $\mathrm{ZnO}$ yang dihasilkan (prinsip ekstraksi). Pada konsentrasi $\mathrm{H}_{2} \mathrm{SO}_{4}$ rendah, hasi ekstraksi $\mathrm{ZnO}$ sangat rendah karena masih banyaknya $\mathrm{ZnO}$ dalam sampel yang belum bereaksi dengan $\mathrm{H}_{2} \mathrm{SO}_{4}$ dan juga adanya senyawa lain yang terikut dalam ekstraksi menggunakan $\mathrm{H}_{2} \mathrm{SO}_{4}$. Adanya $\mathrm{ZnO}$ yang berikatan dengan senyawa lain memerlukan reaksi yang lebih lama, sedangkan dengan konsentrasi $\mathrm{H}_{2} \mathrm{SO}_{4}$ yang tinggi, $\mathrm{ZnO}$ akan mudah larut, sehingga hasil ekstraksinya lebih banyak.
Untuk hasil ekstrasi menggunakan $\mathrm{HCl}$, data dapat dilihat pada Tabel 3 .

Dari Tabel 3, didapatkan data bahwa $\mathrm{ZnO}$ murni bisa didapat dengan menggunakan pelarut $\mathrm{HCl} 0,75 \mathrm{M}$, yaitu $79,23 \%$ dan rendemennya $81,70 \%$, sedangkan konsentrasi 0,25 M hanya didapat kemur-nian sebanyak $74,37 \%$ dengan rendemen sebesar 30,23\%. Data hasil analisis secara titrimetri ini diperkuat dengan hasil analisis menggunakan XRF yang ditampilkan pada Tabel 4. Semakin tingginya konsentrasi $\mathrm{HCl}$ yang digunakan, semakin banyak pula $\mathrm{HCl}$ yang bereaksi dengan $\mathrm{ZnO}$, sehingga se-makin tinggi pula kemurnian yang didapat.

Hasil yang ditampilkan pada Tabel 2 dan Tabel 3 dan didukung dengan data pada Tabel 4 maka perbandingan hasil $\mathrm{ZnO}$ yang diperoleh dari hasil ekstraksi dengan menggunakan larutan Asam sulfat dan asam klorida dapat dilihat pada Gambar 3.
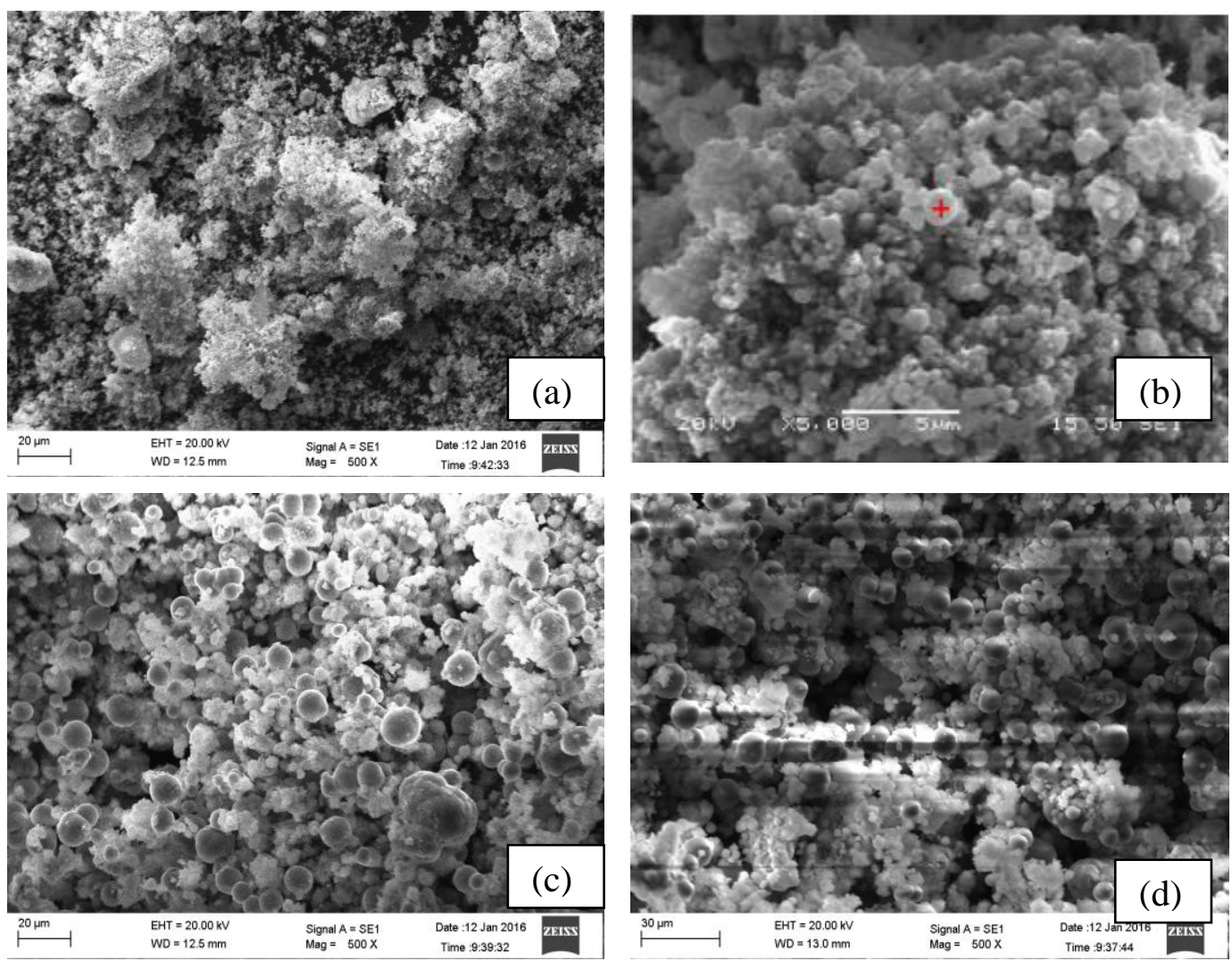

Gambar 1. Bentuk Morfologi (a) Debu Filter (b) Hasil Leaching ZnO (Oustadakis, 2010)

(c) Hasil Leaching dengan $\mathrm{H}_{2} \mathrm{SO}_{4}$ dan (d) Hasil Leaching dengan $\mathrm{HCl}$ 
Tabel 2. Hasil Ekstraksi Debu Filter Proses Pembuatan Baja dengan Pelarut $\mathrm{H}_{2} \mathrm{SO}_{4}$

\begin{tabular}{cccc}
\hline Konsentrasi $\mathrm{H}_{2} \mathrm{SO}_{4}$ & $\begin{array}{c}\text { Padatan yang } \\
\text { Diperoleh Hasil } \\
\text { Ekstraksi }\end{array}$ & Kemurnian ZnO & Rendemen \\
\hline $\mathbf{0 , 2 5}$ M & $8,23 \mathrm{~g}$ & $76,48 \%$ & $46,95 \%$ \\
$\mathbf{0 , 5 0} \mathbf{M}$ & $10,49 \mathrm{~g}$ & $80,45 \%$ & $62,96 \%$ \\
$\mathbf{0 , 7 5} \mathbf{M}$ & $14,61 \mathrm{~g}$ & $89,67 \%$ & $97,73 \%$ \\
\hline
\end{tabular}

Tabel 3. Hasil ekstraksi debu filter proses pembuatan baja dengan pelarut $\mathrm{HCl}$

\begin{tabular}{cccc}
\hline $\begin{array}{c}\text { Konsentrasi } \\
\text { HCl }\end{array}$ & $\begin{array}{c}\text { Padatan yang diperoleh } \\
\text { hasil ekstraksi }\end{array}$ & Kemurnian ZnO & Rendemen \\
\hline $\mathbf{0 , 2 5} \mathbf{M}$ & $5,45 \mathrm{~g}$ & $74,37 \%$ & $30,23 \%$ \\
$\mathbf{0 , 5 0} \mathbf{M}$ & $8,53 \mathrm{~g}$ & $76,98 \%$ & $49,00 \%$ \\
$\mathbf{0 , 7 5} \mathbf{M}$ & $13,82 \mathrm{~g}$ & $79,23 \%$ & $81,70 \%$ \\
\hline
\end{tabular}

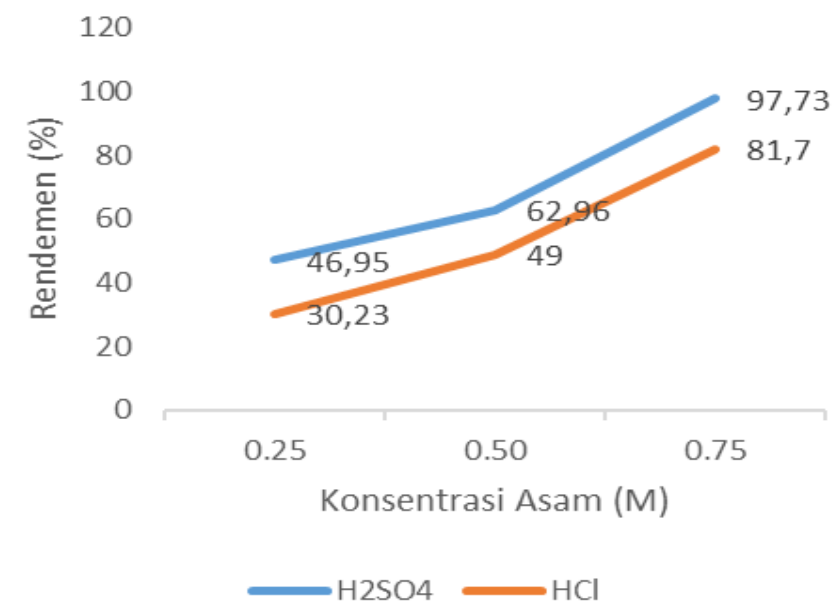

Gambar 2. Grafik Kemurnian $\mathrm{ZnO}$ dengan Pelarut $\mathrm{HCl}$ dan $\mathrm{H}_{2} \mathrm{SO}_{4}$

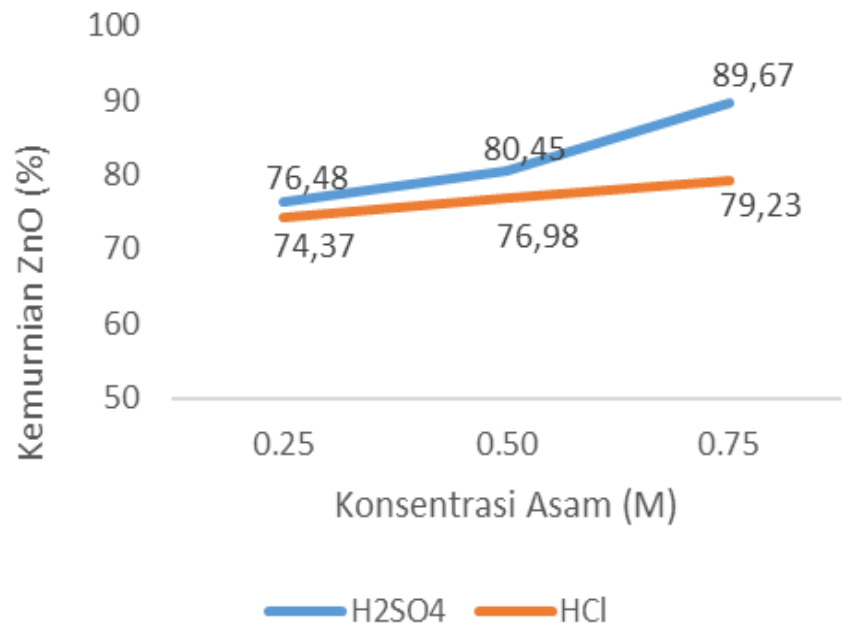

Gambar 3. Grafik Rendemen Hasil Ekstraksi dengan Pelarut $\mathrm{HCl}$ dan $\mathrm{H}_{2} \mathrm{SO}_{4}$ 
Tabel 4. Hasil Analisis Komposisi Ekstrak $\mathrm{ZnO}$

\begin{tabular}{ccccccc}
\hline Parameter & \multicolumn{3}{c}{$\mathbf{H}_{\mathbf{2}} \mathbf{S O}_{\mathbf{4}}$} & & & $\mathbf{H C l}$ \\
& $0,25 \mathrm{M}$ & $0,50 \mathrm{M}$ & $0,75 \mathrm{M}$ & $0,25 \mathrm{M}$ & $0,50 \mathrm{M}$ & $0,75 \mathrm{M}$ \\
\hline $\mathbf{Z n O}$ & $76,42 \%$ & $80,18 \%$ & $88,84 \%$ & $74,32 \%$ & $76,65 \%$ & $78,63 \%$ \\
$\mathbf{M g O}$ & $6,24 \%$ & $2,33 \%$ & $1,72 \%$ & $3,46 \%$ & $2,56 \%$ & $2,18 \%$ \\
$\mathbf{N a}_{2} \mathbf{O}$ & $4,26 \%$ & $4,89 \%$ & $1,32 \%$ & $4,26 \%$ & $3,8 \%$ & $2,04 \%$ \\
$\mathbf{S O}_{3}$ & $1,02 \%$ & $1,108 \%$ & $1,86 \%$ & $0,5 \%$ & $0,5 \%$ & $0,4 \%$ \\
$\mathbf{C a O}$ & $1,2 \%$ & $1,25 \%$ & $1,39 \%$ & $9,27 \%$ & $8,56 \%$ & $6,48 \%$ \\
$\mathbf{C l}$ & & & $0,58 \%$ & $1,36 \%$ & $1,39 \%$ & $1,16 \%$ \\
\hline
\end{tabular}

Gambar 2, menunjukkan bahwa konsentrasi berbanding lurus dengan hasil kemurnian, semakin tinggi konsentrasi yang digunakan, semakin tinggi pula kemurnian yang didapatkan. Kemurnian yang didapat, belum memenuhi baku mutu standar seng oksida jika hendak digunakan untuk rubber,

baik pada proses pelarutan dengan asam sulfat maupun asam klorida.

Gambar 3, dapat dilihat bahwa konsentrasi pelarut berbanding lurus dengan rendemen yang diperoleh. Semakin tinggi konsentrasi pelarut yang digunakan, semakin tinggi juga rendemen yang dihasilkan. Apabila melihat Gambar 2 dan Gambar 3, apabila konsentrasi dinaikan lagi, kecen-derungan kenaikan kemurnian maupun rendemen tidak akan terlalu signifikan, kecuali apabila dilakukan isolasi $\mathrm{ZnO}$ dari zat lain yang ikut terendapkan.

Gambar 2 dan Gambar 3 juga menyajikan bahwa, kemampuan $\mathrm{H}_{2} \mathrm{SO}_{4}$ lebih baik dari pada $\mathrm{HCl}$ dalam melarutkan $\mathrm{ZnO}$. Kemampuan yang dimiliki $\mathrm{H}_{2} \mathrm{SO}_{4}$ ini dikarenakan oleh perbedaan tingkat keasaman antara $\mathrm{HCl}$ dan $\mathrm{H}_{2} \mathrm{SO}_{4}$ dalam konsentrasi yang sama. Perbedaan tingkat keasaman akan sangat berpengaruh terhadap hasil kali kelarutan (Ksp) ZnO. Semakin rendah $\mathrm{pH}$ suatu larutan, maka banyaknya ion $\mathrm{Zn}^{2+}$ yang terlarut akan semakin banyak. Jika diendapkan dengan bantuan natrium karbonat, akan semakin banyak pula endapannya. $\mathrm{H}_{2} \mathrm{SO}_{4}$ merupakan asam berbasa dua yang mempunyai dua ion $\mathrm{H}^{+}$. Keberadaan ion $\mathrm{H}^{+}$ini yang menyebabkan kekuatan asam semakin tinggi.
Tingkat kemurnian hasil ekstraksi dipengaruhi oleh adanya senyawa lain yang ikut terekstrak bersama $\mathrm{ZnO}$, baik itu dari bahan awalnya (debu filter) atau dari pe-nambahan beberapa bahan kimia pada saat pengendapan ion $\mathrm{Fe}$ dan $\mathrm{Zn}$. Adapun data komposisi hasil ekstraksi $\mathrm{ZnO}$ yang dianalisis menggunakan XRF dapat dilihat pada Tabel 4.

Berdasarkan Tabel 4, dapat kita lihat bahwa adanya senyawa lain yang ikut terekstrak seperti $\mathrm{MgO}$ dan $\mathrm{CaO}$ yang berasal dari debu filter, menyebabkan kemurnian $\mathrm{ZnO}$ semakin kecil, $\mathrm{MgO}$ dan $\mathrm{CaO}$ adalah logam yang dapat larut dalam asam dan dapat mengendap dengan basa. Selain itu, adanya penambahan $\mathrm{NaCO}_{3}$ untuk proses pengendapan $\mathrm{ZnCO}_{3}$, menyebabkan oksida logam tersebut ikut serta dalam hasil ekstraksi.

\section{KESIMPULAN}

$\mathrm{ZnO}$ dari debu filter pada proses pembuatan baja dapat dipisahkan dengan cara ekstraksi padat cair menggunakan asam sulfat dan asam klorida. Asam sulfat memberikan kemurnian lebih baik pada konsentrasi yang sama dibandingkan dengan asam klorida yaitu pada konsentrasi $0,75 \mathrm{M}$ dengan peroleh kemurnian $89,67 \%$ dan rendemen $97,73 \%$. 


\section{DAFTAR PUSTAKA}

American Society for Testing and Materials. 1999. Standard Classification for Rubber Compounding Materials-Zinc Oxide. ASTM D 4295. USA.

Badan Standarisasi Nasional. 2009. Seng Oksida. (SNI 0085 : 2009). Jakarta.

Calbeck, J.H. 1952. United States Patent: Production of Zinc Oxide. Patent No. 2,603,554. United States.

Choi, Yeonuk., S. Payant, J. Kim, A. Maria Giove, R. Rao, dan J. Andrew Finch. 2004. United States Patent: Production of Zinc Oxide from Acid Soluble Ore Using Precipitation Method. Patent No. 6,726,889 B2. United States.

Furniss, B.S. 1989. Vogel's Textbook of Practical Organic Chemistry 5th Edition. Thames Polytechnic. London.

Guillaume, P.C., Devos, G.G., dan Rous, J.L. 2008. Recycling Residues into Metals. Millenium Steel. London. United Kingdom.

Havlik, Tomas, Bernd Friedrich, Srecko Stopic. 2004. Pressure Leaching of EAF Dust with Sulphric Acid. World of Metallurgy. Erzmetall. Vol 57 (2) : 1-8.

Hyman, Mark. 1989. Evidentiary Certificate on Zinc Ash. Diakses $28 \quad$ Mei 2013. http://environment.gov.au/settlem ents/chemicals/hazardouswaste/publications-evidentiaryzinc-ash.html

Juergen, R. 2007. Application of Waelz Technology on Resources: Recycling of Steel Mill Dust. Metallurgieshes Seminar, Heft
XYZ der Schrifenreihe der GDMB. Leoben. Germany

Kui Xia. 1997. Recovery of Zinc from Zinc Ferrite and Electric Arc Furnace Dust. Thesis. Queen's University Kingston Ontario. Canada.

Langova S. dan D. Matysek. 2010. Zinc recovery from steel-making wastes by acid pressure leaching and hematite precipitation. Elsevier. 101: 171 - 173.

Outstadakis P. 2010. Hydrometallurgi-cal Process for Zinc Recovery from Electric Arc Furnace Dust (EAFD). Department of Mining and Metallurgical Engineering. Journal of Hazardous Materials.

Pan-Continental Chemical Co., Ltd. Active Zinc Oxide. Diakses 28 Mei 2014. http://www.pccchemical.com/

Rosenqvist, Terkel. 2004. Extractive Metallurgy. Jilid II. Tapir Academic Press. Norwegia

Wannakamb,

Sirinart,S

Manuskijsamrun, W. Buggakupta. 2013. The Use of Electric Arc Furnace Dust from Steel Recycling in Ceramic Glaze. Suranaree. J. Sci. Technol. 20 (4): 329-337.

Yoshida, Takashi. 2003. Leaching of Zinc Oxide in Acidic Solution. The Japan Institute of Metals. Journal of Material Transactions. 44: 2489-2493. 